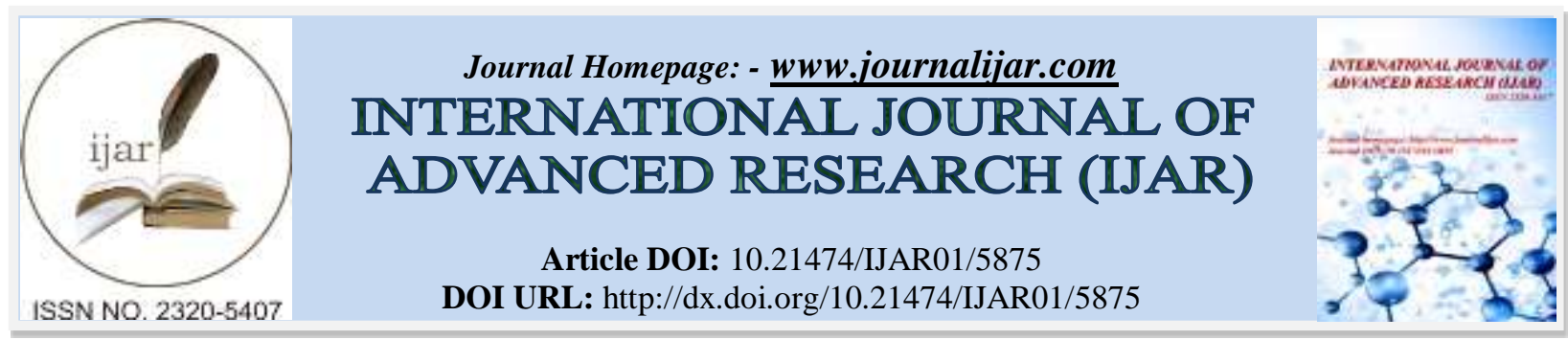

RESEARCH ARTICLE

\title{
AN OPTIMUM EVALUATION OF FOUR DIFFERENT NIGERIAN PORTLAND CEMENTS FOR HIGHWAY RIGID PAVEMENTS.
}

\author{
Isaac Akiije. \\ Department of Civil and Environmental Engineering, Faculty of Engineering, University of Lagos, Akoka, Yaba, \\ Lagos, Nigeria.
}

\section{Manuscript Info}

Manuscript History

Received: 15 September 2017

Final Accepted: 17 October 2017

Published: November 2017

Key words:-

Development, Concrete, Granites, Sand,

Cement, Brands.

\begin{abstract}
This study investigated the trend of four different types of new brands of cement that are produced locally in Nigeria for optimum selection while producing concrete for highway pavement. The four brands of portland cements used individually in the course of producing the investigated concretes are tagged $42.5 \mathrm{Rd}, 32.5 \mathrm{Rs}, 42.5 \mathrm{~Np}$ and 32.5 Rt. It involved using nominal maximum size of $19 \mathrm{~mm}$ granite as coarse aggregate in the individual concrete production. Coarser river sand with fineness modulus of 3.0 along was used with water cement ratio of 0.4 to produce the said individual cement concrete of ratio 1:1.5:3 mixtures. The four different types of cement were individually subjected to tests that included specific gravity, fineness, consistency, setting time, chemical and metallic compositions. The coarse aggregate used was subjected to crushing, impact and abrasion tests. Aggregate gradation tests were also carried out on both fine and coarse aggregates. Each brand of fresh concrete produced based upon the cement type was subjected to slump and compaction factor tests. Compressive, tensile splitting and flexural strength tests were carried out on hardened concrete specimens. At 28 days curing, the use of $19 \mathrm{~mm}$ maximum size of aggregate proffered concrete flexural strength ranging from 3.6 $\mathrm{N} / \mathrm{mm}^{2}$ to $4.8 \mathrm{~N} / \mathrm{mm}^{2}$ Significantly, it is the use of $42.5 \mathrm{~Np}$ cement only that satisfied the minimum requirement value for flexural strength of $4.5 \mathrm{~N} / \mathrm{mm}^{2}$ at 28 days curing for highway pavement design and construction. The justification for this study is the identification of the uniqueness of the $42.5 \mathrm{~Np}$ cement having a breakthrough among the peering cements for being singularly satisfying standard specification requirements in this facets.
\end{abstract}

Copy Right, IJAR, 2017,. All rights reserved.

\section{Introduction:-}

The selection of a particular brand of cement among various ones in the production of concrete for highway pavement design and construction can possibly be a concern at construction site. This is because it is necessary to produce useful and desirable concrete for rigid pavement which must meet standard specification requirement at optimum level of strength and durability. Also, required aggregates in the production of concrete are to be clean, tough, hard and of durable grains. It is pertinent to note that freshly mixed concrete must have acceptable

Corresponding Author:- Isaac Akiije.

Address:- Department of Civil and Environmental Engineering, Faculty of Engineering, University of 1120 Lagos, Akoka, Yaba, Lagos, Nigeria. 
workability by way of water cement ratio. Also, hardened cement concrete formed must possess uniform appearance, adequate strength, acceptable durability and economy that satisfied a required standard specification.

Drinkable water is usually suitable in the production of concrete although some non-drinkable water may also be useful depending upon the degree of impurities. Mamlouk and Zaniewski (2006) claimed that impurities in the mixing water can affect concrete setting time, strength and long-term durability while the presence of chloride ions in same can accelerate corrosion of reinforcing steel.

According to ASTM C150 (2013), cement types are categorized as I, IA, II, IIA, III, IIIA, IV and V based on their individual standard properties. Mamlouk and Zaniewski (2006) claimed that the use of air-entrained cements which are Types IA, IIA, and IIIA has diminished due to improved availability and reliability of the air entrainer or admixtures that can be added during concrete mixing.

According to ASTM C33 (2016) and AASHTO M 6 (2013) aggregates are classified by standard specification for concrete production as fine and coarse. Fine aggregate are of natural sand, river bed sand, manufactured sand, or a combination thereof with particles that are typically smaller than $4.75 \mathrm{~mm}$. Also, coarse aggregate are of gravel, crushed gravel, crushed stone, air-cooled blast furnace slag, or crushed concrete, or a combination of with particles generally larger than $4.75 \mathrm{~mm}$.

This research utilized aggregates with nominal maximum size of $19 \mathrm{~mm}$ in the production of cement concrete optimally for highway pavement design and construction. Concrete is formed when water is added with cement and sometimes admixture for chemical reaction process called hydration to take place in addition of aggregates. The material formed in the process along with age hardened with gaining strength to form a rock-like structure. In the process, it is pertinent to note that the finer the cement the larger its surface area, the greater the heat of hydration and the faster in the development of concrete strength. When concrete is newly mixed it is in a plastic state and later hardened to strong and durable construction material. The phenomenon is based upon using durable aggregates and higher weight of cement in the mixture with lower water cement ratio and workable lower compacting factor hence higher strength and durability.

Ikponmwosa et al. (2014) investigated upon the suitability of crushed palm kernel shell as coarse aggregate in the production of normal weight structural concrete using same as partial replacement of granite. Here, concrete was made of ratio 1:2:4 mix with constant w/c ratio of 0.65 along with substituting granite with crushed palm kernel shells (PKS) from $0 \%$ to $50 \%$ at $10 \%$ intervals. At 28-day curing age compression tests, the compressive strength

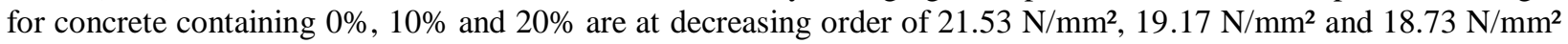
respectively. The researchers in this facet recommended that concrete as produced in the study could be used in the production of minor elements especially in rural areas with abundance of PKS. It should be noted that highway pavement could not be regarded as minor element in concrete design and construction. It should be noted that Wright and Dickson (2004) claimed that cement concrete of flexural strength of $4.5 \mathrm{~N} / \mathrm{mm}^{2}$ value is commonly the minimum required strength in highway pavement design and construction. O'Flaherty (2002) claimed that grade $\mathrm{C} 40$ concrete is the required compressive strength for highway pavement design and construction.

This research aims at investigating the potentials of concrete while using nominal maximum $19 \mathrm{~mm}$ granite aggregate. In the process, four newly produced brands of cements that are made in Nigeria were employed whilst optimizing same for the purpose of highway pavement design and construction independently. Specifically the objectives of this research are to:

1. Define individually the specific chemical and metallic composition properties of the four cements used together with the determination of their initial and final setting times;

2. Determine the particle size distribution for both the fine and coarse aggregates along with their fineness modulus, coefficient of uniformity and coefficient of curvature;

3. Determine the crushing, impact and abrasion values of coarse aggregates used;

4. Define and compare different concretes made of the four different types of cement independently while using same river sand, water, nominal maximum size of $19 \mathrm{~mm}$ granite individually;

5. Determine and compare individually the workability of each of the four different types of fresh concretes prepared through their slump tests and the compacting factor tests separately and;

6. Carry out laboratory tests to destruction of hardened concrete specimens in order to determine flexural, compressive and tensile strengths. 
The main scope of work in this study therefore includes using individually four brands of cement which are tagged 42.5 Rd, $32.5 \mathrm{Rs}, 42.5 \mathrm{~Np}$ and $32.5 \mathrm{Rs}$, and employing $19 \mathrm{~mm}$ granite along with the use of river sand and potable water. Concrete materials mixture ratio is 1:1.5:3 with water cement ratio of 0.4. Significantly, this study provides information upon the differences that occurred in relationship to the developed strengths while using nominal maximum size of $19 \mathrm{~mm}$ granite as aggregate in proportioning of concrete mixes for highway pavement design and construction. The justification for this research work is in the enlightenment in the optimization of the potentials of the four different brands of the cements used for due economy while designing and constructing highway rigid pavement.

\section{Materials and Methodology:- Materials classifications:-}

The following newly four improved made in Nigeria portland cements which are tagged $42.5 \mathrm{Rd}, 32.5 \mathrm{Rs}, 42.5 \mathrm{~Np}$ and 32.5 Rt were employed independently in the production of separate concrete. The separate cement concrete was produced using river sand, water and nominal maximum size of $19 \mathrm{~mm}$ granites. Each cement brand used was ordinary portland cement Type I whose properties conformed to AASHTO T 85 (2009). Type I Portland cement used is considered here being suitable for general concrete construction and where no special properties are required. The cements were supplied in $50 \mathrm{~kg}$ per bag and were well protected in the laboratory from dampness by placing them on planks to avoid lumps development within the material before use. Each bag of cement when opened was used within 30 minutes for the purpose of casting the required specimens in the laboratory.

The relative density or specific gravity of cement used was determined according to ASTM C 188 (2015) whilst the bulk density was determined as its weight per unit volume. Each cement fineness determination was carried out by the percent passing the $0.045 \mathrm{~mm}$ sieve in accordance to ASTM C 430 (2008) procedure for the four different types of cements used in this research independently. The cement was subjected to initial and final setting time tests based on measurements by the Vicat apparatus according to ASTM C 191(2013). Atomic absorption spectrometer methodology with high performance of low detection limits with accuracy was adopted in the laboratory to carry out the cement chemical elements composition and metallic components using the absorption of optical radiation by free atoms in the gaseous state.

Potable water found in the concrete laboratory of the department of Civil and Environmental Engineering, University of Lagos was found to be free of chloride ions, oil, alkalis and acids before being used in the production of the concrete specimens.

Ogun river sand from Lagos environs was used in the production of the concrete investigated upon in this research work. For the laboratory examination, the sand used was oven dried to the average temperature of $32 \pm 2^{\circ} \mathrm{C}$ for grain sieve analysis. The gradation test was performed on the fine aggregate sample that passed through sieve $9.5 \mathrm{~mm}$ and retained on $0.15 \mathrm{~mm}$ after agitation of nest of the sieves according to AASHTO T 27 (2014). In the process, a nest of sieves with apertures $9.5 \mathrm{~mm}, 4.75 \mathrm{~mm}, 2.36 \mathrm{~mm}, 1.18 \mathrm{~mm}, 0.60 \mathrm{~mm}, 0.30 \mathrm{~mm}$ and $0.15 \mathrm{~mm}$ were used for the grain-size classification. Also, the specific gravity of the fine aggregate used was determined according to AASHTO T 85 (2009) specification.

Nominal maximum size of $19 \mathrm{~mm}$ granite quarried at Abeokuta environs in Ogun State of Nigeria and sold at Bariga in Lagos was use in the production of concrete for this study. Also, coarse aggregate sample was oven dried in laboratory for the purpose of sieve analysis tests. In the process, a nest of sieves with apertures $25 \mathrm{~mm}, 19.0 \mathrm{~mm}$, $12.5 \mathrm{~mm}, 9.5 \mathrm{~mm}, 4.75 \mathrm{~mm}, 2.36 \mathrm{~mm}, 1.18 \mathrm{~mm}, 0.60 \mathrm{~mm}, 0.30 \mathrm{~mm}$ and $0.15 \mathrm{~mm}$ was used for the coarse aggregate gradation according to AASHTO T 27 (2014). The specific gravity of the coarse aggregate used was determined according to AASHTO T 84 (2013) specification. The bulk density of the coarse aggregate used was determined according to AASHTO T 19 (2014) specification.

Proportioning of the concrete mixtures:-

Each type of cement was mixed individually using water cement ratio (w/c) 0.4 and nominal maximum size of 19 $\mathrm{mm}$ granite along with same river sand with a mixing ratio of 1:1.5:3 for the production of the laboratory specimens. The computation of the proportioning of materials for the production of cement concrete specimens meant for testing flexural, compressive and tensile strengths specimens are shown in Table 1. Table 2 is showing the determinations of concrete specimens' volume per batch of production. 
Both the absolute volume and weight methods are considered in this research while proportioning water, cement, fine aggregate and coarse aggregate for the attempt to obtain satisfactory concrete strength, durability and economy when used for highway pavement. In the facet, the specific gravity and bulk density of each material to produce concrete using a bag of $50 \mathrm{~kg}$ cement with other constituents were adequately considered. Afterwards, the volume obtained is converted into weight for the determination of the batching of the concrete constituents that is readily useful in the laboratory for the preparation of sample specimens for strength tests.

Equation 1, is a useful model for the determination of cement concrete per volume batch $V_{c b}$ of production Gambhir (2004) and it is given by

$V_{c b}=\frac{w}{\gamma_{w}}+\frac{c}{\gamma_{w} S_{c}}+\frac{f_{a}}{\gamma_{w} S_{f a}}+\frac{c a}{\gamma_{w} S_{c a}}$

Where, $w$ is the weight of water, $\gamma_{w}$ is the density of water whilst $c$ is the weight of cement, $f a$ is the weight of fine aggregate, $c a$ is the weight of coarse aggregate and their respective specific gravity are $S c, S f a$ and $S c a$ respectively. The expressions in Equation 1 are useful modalities for the possibility of obtaining absolute concrete volume Vca per $50 \mathrm{~kg}$ bag of portland cement in $\mathrm{m}^{3}$ Akiije (2017) as described in Table 3 through Table 5.

Table 1:- Determinations of concrete specimens per batch and of production

\begin{tabular}{|c|c|c|c|c|c|c|c|c|c|}
\hline Label & \multicolumn{5}{|c|}{ Water Cement Ratio (w/c) } & Cement & River Sand & \multicolumn{2}{|c|}{ Granite } \\
\hline Mix Ratio & \multicolumn{5}{|l|}{0.4} & 1 & 1.5 & \multicolumn{2}{|l|}{3} \\
\hline Concrete Tests & \multicolumn{5}{|c|}{ Flexural Strength } & \multicolumn{2}{|c|}{ Compressive Strength } & \multicolumn{2}{|c|}{ Tensile Strength } \\
\hline $\begin{array}{lll}\text { Concrete } & \text { Shapes } & \text { and } \\
\text { Dimensions } & & \\
\end{array}$ & \multicolumn{5}{|c|}{$(550 \times 150 \times 150) \mathrm{mm}$} & \multicolumn{2}{|c|}{$(150 \times 150 \times 150) \mathrm{mm}$} & \multicolumn{2}{|c|}{$(300 \times 150) \mathrm{mm}$} \\
\hline Curing Ages (Days) & 7 & 28 & 56 & 91 & 120 & 7 & 28 & 7 & 28 \\
\hline $\begin{array}{l}\text { Number Concrete } \quad \text { Beam } \\
\text { Specimens using 42.5 Rd OPC }\end{array}$ & 3 & 3 & 3 & 3 & 3 & 3 & 3 & 3 & 3 \\
\hline $\begin{array}{l}\text { Number Concrete } \\
\text { Specimens using } 32.5 \text { Rs OPC }\end{array}$ & 3 & 3 & 3 & 3 & 3 & 3 & 3 & 3 & 3 \\
\hline $\begin{array}{l}\text { Number Concrete } \\
\text { Specimens using } 42.5 \text { Rp OPC }\end{array}$ & 3 & 3 & 3 & 3 & 3 & 3 & 3 & 3 & 3 \\
\hline $\begin{array}{l}\text { Number Concrete } \quad \text { Beam } \\
\text { Specimens using } 32.5 \text { Rt OPC }\end{array}$ & 3 & 3 & 3 & 3 & 3 & 3 & 3 & 3 & 3 \\
\hline $\begin{array}{l}\text { Number Concrete } \\
\text { Specimens Sub Total }\end{array}$ & 12 & 12 & 12 & 12 & 12 & 12 & 12 & 12 & 12 \\
\hline $\begin{array}{l}\text { Number Concrete Beam } \\
\text { Specimens Total }\end{array}$ & 60 & & & & & 24 & & 24 & \\
\hline
\end{tabular}

Table 2:- Determinations of concrete specimens' volume per batch of production

\begin{tabular}{|c|c|c|c|c|c|c|c|c|}
\hline Label & Length & Width & Height & Radius & Volume & $\begin{array}{l}\text { Number of } \\
\text { Specimens }\end{array}$ & $\begin{array}{ll}\text { Sub } & \text { total } \\
\text { Volume } & \end{array}$ & Total Volume \\
\hline Beam & 0.55 & 0.15 & 0.15 & & $\begin{array}{l}0.01237 \\
5\end{array}$ & 15 & 0.185625 & \multirow[t]{3}{*}{0.238} \\
\hline Cube & 0.15 & 0.15 & 0.15 & & $\begin{array}{l}0.00337 \\
5\end{array}$ & 6 & 0.02025 & \\
\hline Cylinder & 0.3 & & & 0.075 & $\begin{array}{l}0.00530 \\
4\end{array}$ & 6 & 0.0318 & \\
\hline $\begin{array}{l}\text { Less } 2 \% \\
\text { Air } \\
\text { Entrainment }\end{array}$ & & & & & & & $0.98 \times 0.23=$ & 0.233 \\
\hline $\begin{array}{l}\text { Add } 3 \% \\
\text { Wastage }\end{array}$ & & & & & & & $1.01 \times 0.23=$ & 0.235 \\
\hline
\end{tabular}


Table 3:- Expressions for a batch computation of the absolute volume and absolute weight of concrete

\begin{tabular}{|c|c|c|c|c|c|c|}
\hline & $\mathrm{C}$ & $\mathrm{D}$ & $\mathrm{E}$ & $\mathrm{F}$ & $\mathrm{G}$ & $\mathrm{H}$ \\
\hline 5 & Constituents & Water & Cement & Fine Aggregate & $\begin{array}{c}\text { Coarse } \\
\text { Aggregate }\end{array}$ & Sum \\
\hline 6 & Assumed Proportion & $w / c$ & $c$ & $\beta$ & $\omega$ & \\
\hline 7 & Bulk Density & $\gamma_{w}$ & $\gamma_{c}$ & $\gamma_{f a}$ & $\gamma_{c a}$ & \\
\hline 8 & Applied Ratio by Weight & $w / c$ & $c$ & $\frac{\beta \times \gamma_{f a}}{\gamma_{c}}$ & $\frac{\omega \times \gamma_{c a}}{\gamma_{c}}$ & \\
\hline 9 & Specific Gravity & $S_{w}$ & $S_{c}$ & $S_{f a}$ & $S_{c a}$ & \\
\hline 10 & $\begin{array}{l}\text { Absolute concrete volume } \\
\text { Vca, per } 50 \mathrm{~kg} \text { cement } \\
\text { bag, } \mathrm{m}^{3}\end{array}$ & $\begin{array}{l}\frac{w / c \times 50}{\gamma_{w} \times S_{w}} \\
=\mathrm{j}\end{array}$ & $\begin{array}{l}\frac{\alpha \times \gamma_{c} \times 50}{\gamma_{w} \times \gamma_{c} \times S_{c}} \\
=\mathrm{k}\end{array}$ & $\begin{array}{c}\frac{\beta \times \gamma_{f a} \times 50}{\gamma_{w} \times \gamma_{c} \times S_{f a}} \\
=1\end{array}$ & $\begin{array}{c}\frac{\omega \times \gamma_{c a} \times 50}{\gamma_{w} \times \gamma_{c} \times S_{c a}} \\
=\mathrm{m}\end{array}$ & $\begin{array}{c}\mathrm{V}= \\
\mathrm{j}+\mathrm{k}+\mathrm{l}+\mathrm{m}\end{array}$ \\
\hline 11 & $\begin{array}{l}\text { Concrete weight Wca for } \\
\text { one bag of cement, } \mathrm{kg}\end{array}$ & $\mathrm{V} * 50 * w / c$ & $V^{*} 50$ & $\mathrm{~V} * 50 * \frac{\beta \times \gamma_{f a}}{\gamma_{c}}$ & $\mathrm{~V} * 50 * \frac{\omega \times \gamma_{c a}}{\gamma_{c}}$ & $\mathrm{~W}=$ \\
\hline 12 & $\begin{array}{l}\text { Concrete weight Wca for } \\
1 \text { metre cube of concrete }\end{array}$ & $\begin{array}{l}1 /(V * 50) * \\
(w / c)\end{array}$ & $1 / V * 50$ & $1 / V^{*} t$ & $1 / V * u$ & Wv \\
\hline 13 & $\begin{array}{l}\text { Concrete volume Vcca, } \\
\text { litres of cement bag, } \mathrm{m}^{3}\end{array}$ & $j * \gamma_{w}$ & Vcb & $\mathrm{Vcb} * 1 / \mathrm{k}$ & $\mathrm{Vcb} * \mathrm{~m} / \mathrm{k}$ & Vec \\
\hline 14 & Applied Ratio by Volume & $\mathrm{j} / \mathrm{k}$ & $\mathrm{k} / \mathrm{k}$ & $1 / \mathrm{k}$ & $\mathrm{m} / \mathrm{k}$ & \\
\hline
\end{tabular}

Table 4:- Modelling of absolute volume and absolute weight of concrete per batch of 0.4 water cement ratio

\begin{tabular}{|c|c|c|c|c|c|c|}
\hline & $\mathrm{C}$ & $\mathrm{D}$ & $\mathrm{E}$ & $\mathrm{F}$ & $\mathrm{G}$ & $\mathrm{H}$ \\
\hline 5 & Constituents & Water & Cement & $\begin{array}{l}\text { Fine } \\
\text { Aggregate }\end{array}$ & $\begin{array}{l}\text { Coarse } \\
\text { Aggregate }\end{array}$ & Total \\
\hline 6 & Assumed Proportion & & 1 & 1.0515 & 2.047 & \\
\hline 7 & Bulk Density & 1000 & 1160 & 1655 & 1600 & \\
\hline 8 & Applied Ratio by Weight & 0.4 & $=\mathrm{E} 6 * \mathrm{E} 7 / \mathrm{E} 7$ & $=\mathrm{F} 6 * \mathrm{~F} 7 / \mathrm{E} 7$ & $=\mathrm{G} 6 * \mathrm{G} 7 / \mathrm{E} 7$ & \\
\hline 9 & Specific Gravity & 1 & 3.15 & 2.67 & 2.67 & \\
\hline 10 & $\begin{array}{l}\text { Absolute concrete volume } \\
\text { Vca, per } 50 \mathrm{~kg} \text { cement bag, } \\
\mathrm{m}^{3}\end{array}$ & $\begin{array}{l}=\mathrm{D} 8 * 50 / \\
1000 / \mathrm{D} 9\end{array}$ & $\begin{array}{l}=\mathrm{E} 8 * 50 / \\
1000 / \mathrm{E} 9\end{array}$ & $\begin{array}{l}=\mathrm{F} 8 * 50 / \\
1000 / \mathrm{F} 9\end{array}$ & $\begin{array}{l}=\mathrm{G} 8 * 50 / \\
1000 / \mathrm{G} 9\end{array}$ & $\begin{array}{l}=\text { SUM } \\
\text { (D10:G10) }\end{array}$ \\
\hline 11 & $\begin{array}{l}\text { Concrete weight Wca for } \\
\text { one bag of cement, } \mathrm{kg}\end{array}$ & $=\mathrm{E} 11 * \mathrm{D} 8$ & $\begin{array}{l}=\mathrm{H} 10 / \\
\mathrm{H} 10 * 50\end{array}$ & $=\mathrm{E} 11 * \mathrm{~F} 8$ & $=\mathrm{E} 11 * \mathrm{G} 8$ & $\begin{array}{l}=\text { SUM } \\
\text { (D11:G11) }\end{array}$ \\
\hline 12 & $\begin{array}{l}\text { Concrete weight Wca for } 1 \\
\text { metre cube of concrete }\end{array}$ & $=\mathrm{E} 12 * \mathrm{D} 8$ & $=1 / \mathrm{H} 10 * 50$ & $=1 / \mathrm{H} 10 * \mathrm{~F} 11$ & $=1 / \mathrm{H} 10 * \mathrm{G} 11$ & $\begin{array}{l}=\text { SUM } \\
\text { (D12:G12) }\end{array}$ \\
\hline 13 & $\begin{array}{l}\text { Concrete volume Vcca, } \\
\text { litres of cement bag, } \mathrm{m}^{3}\end{array}$ & $=\mathrm{D} 10 * 1000$ & $=\mathrm{E} 11 * 1000 / \mathrm{E} 7$ & $=\mathrm{F} 11 * 1000 / \mathrm{F} 7$ & $=\mathrm{G} 11 * 1000 / \mathrm{G} 7$ & $\begin{array}{l}=\text { SUM } \\
\text { (D13:G13) }\end{array}$ \\
\hline 14 & Applied Ratio by Volume & $=\mathrm{D} 13 / \mathrm{E} 13$ & $=\mathrm{E} 13 / \mathrm{E} 13$ & $=\mathrm{F} 13 / \mathrm{E} 13$ & $=\mathrm{G} 13 / \mathrm{E} 13$ & \\
\hline
\end{tabular}

Table 5:- Simulation of absolute volume and absolute weight of concrete per batch in relationship to Table 4 Applied Ratio by Weight

\begin{tabular}{|c|c|c|c|c|c|c|}
\hline & $\mathrm{C}$ & $\mathrm{D}$ & $\mathrm{E}$ & $\mathrm{F}$ & $\mathrm{G}$ & $\mathrm{H}$ \\
\hline 5 & Constituents & Water & Cement & $\begin{array}{c}\text { Fine } \\
\text { Aggregate }\end{array}$ & $\begin{array}{c}\text { Coarse } \\
\text { Aggregate }\end{array}$ & Total \\
\hline 6 & Assumed Proportion & & 1.000 & 1.052 & 2.047 & \\
\hline 7 & Bulk Density & 1000 & 1160 & 1655 & 1700 & \\
\hline 8 & Applied Ratio by Weight & 0.400 & 1.000 & 1.500 & 3.000 & \\
\hline 9 & Specific Gravity & 1 & 3.15 & 2.67 & 2.67 & \\
\hline 10 & $\begin{array}{l}\text { Absolute concrete volume Vca, } \\
\text { per } 50 \mathrm{~kg} \text { cement bag, } \mathrm{m}^{3}\end{array}$ & 0.020 & 0.016 & 0.028 & 0.056 & 0.120 \\
\hline 11 & $\begin{array}{l}\text { Concrete weight Wca for one bag } \\
\text { of cement, } \mathrm{kg}\end{array}$ & 20 & 50 & 75 & 150 & 295 \\
\hline 12 & Concrete weight Wca for 1 metre & 166 & 416 & 624 & 1248 & 2455 \\
\hline
\end{tabular}




\begin{tabular}{|l|l|l|l|l|l|l|}
\hline & cube of concrete & & & & & \\
\hline 13 & $\begin{array}{l}\text { Concrete volume Vcca, litres of } \\
\text { cement bag, } \mathrm{m}^{3}\end{array}$ & 20 & 43 & 45 & 88 & 197 \\
\hline 14 & Applied Ratio by Volume & 0.464 & 1.000 & 1.052 & 2.047 & \\
\hline
\end{tabular}

In Table 3, expressions for the computation of concrete per batch are defined for the absolute volume Vca and absolute weight Wca. In the process, absolute concrete weight $\mathrm{Wca}$ in $\mathrm{kg}$ per batch is determined by given consideration to specific gravities and bulk densities of the materials used. Firstly, the mixture to be used is assumed in the proportion of part of cement as $c$ of which its value is considered as 1 . Also, fine aggregate and coarse aggregate values by proportioning are expressed as $\beta$ and $\omega$ respectively. Bulk densities of water, cement, fine aggregate and coarse aggregate values are respectively expressed as $\gamma_{w}, \gamma_{c}, \gamma_{f a}$ and $\gamma_{c a}$ while their respective specific gravities are $S w, S c, S f a$ and $S c a$. Also, the respective weight of water, cement, fine and coarse aggregates that form the cement concrete production constituents are defined as $w, c, f_{a}$ and $c_{a}$ respectively. Expressions in Table 3 are possible models representations for Microsoft Excel Spreadsheet sheet. The expressions are useful to form template for the computation of the absolute volume and absolute weight of concrete production per batch. Expressions in Table 3 could be employed as in Table 4 by employing Microsoft Excel Spreadsheet to form a useful modelling template. Table 5 is the simulation of absolute volume and absolute weight of concrete per batch including values of cement concrete constituents as modelled in Table 4 by Excel program sheet.

\section{Materials batching and concrete specimens production:-}

Concrete constituents as shown in Table 5 per $50 \mathrm{~kg}$ of each cement type were utilized in the course of the laboratory specimens. The rotating mixer used was wetted with water and totally drained of it in order to provide a non-absorbent internal surface. Similarly, the platform for placing the concrete from the rotating drum was also wetted with water and drained properly. The rotating mixer was firstly charged with $10 \%$ of the required water solution followed by $50 \%$ of the coarse aggregate, then $100 \%$ of the fine aggregate and followed by $100 \%$ cement and then the remaining $50 \%$ of the coarse aggregate. $80 \%$ of the water requirement was then added into the rotating mixer drum. As the drum is continuously rotating, a minimum total mixing time of 4 minutes was allowed before the mixture was let out on to the platform on the floor. The balance of $10 \%$ of the water remaining was later pour into the rotating mixer and allowed to rotate for about 20 seconds. Then the water together with the remaining cement concrete constituents was poured out directly on top of the concrete mixture already on the platform.

Thereafter, thorough hand mixing was done in order to have the required consistency before the placing of the concrete produced finally into the required moulds to produce each specific specimen. Batching of the mixture using the rotating mixer was carried out two times. This paved way for the use of the earlier oil primed moulds to produce a set of the required specimens of 15 numbers of $150 \mathrm{~mm} \times 150 \mathrm{~mm} \times 550 \mathrm{~mm}$ beams, 6 numbers of $150 \mathrm{~mm} \times 150$ $\mathrm{mm} \times 150 \mathrm{~mm}$ cubes and 6 numbers of $150 \mathrm{~mm} \times 300 \mathrm{~mm}$ cylinders concrete specimens.

Placing of concrete in each mould was done in three layers of which it was tapped with $16 \mathrm{~mm}$ round steel rod of $600 \mathrm{~mm}$ length by 25 strokes per layer. The remaining 3 sets of specimens based on each brand of cement concrete constituents were carried out similarly for batching, mixing, handling of the fresh concrete for making samples and curing but not on the same day because of the availability of specimen moulds and space inside the laboratory.

Demoulding of the specimens of the first set of concrete samples was carried out about $24 \pm 2$ hours of casting and then cured by being covered using fresh water in a tank having the average temperature of $23 \pm 1.7^{\circ} \mathrm{C}$ till the day of testing.

\section{The slump and the compacting factor tests:-}

The slump test was carried out in accordance to AASHTO T 119 (2013) upon the fresh concrete produced within 4 minutes of finishing the mixing of same on the platform. Sump test is a useful assessment for measuring the consistency for the workability value of the fresh concrete produced. The compacting factor test was also carried out according to BS 1881 (2011) upon the fresh concrete produced immediately after carrying out the slump test and within 6 minutes of finishing the mixing of same on the platform. The compacting factor test helps to define the fresh concrete workability based upon its compact or dense ability. The compacting factor value could be calculated by dividing the partially compacted concrete weight by that of the fully compacted concrete of which the value is 
always less than 1 . The lower the compacting factor amount the higher the strength of cement concrete.

\section{Flexural strength test:-}

Flexural strength test was carried out on each of the beam specimen according to ASTM C 78 (2016). Here, each sample of beam $550 \mathrm{~mm}$ by $150 \mathrm{~mm}$ by $150 \mathrm{~mm}$ was tested on a universal testing machine. Third point loadings having two supporting pins of $450 \mathrm{~mm}$ distance $\mathrm{L}$, with two loading pins at equal distance of $150 \mathrm{~mm}$ to each adjacent support method was applied. Overhang distance of $50 \mathrm{~mm}$ at each end was provided for the beam specimen of w, width $150 \mathrm{~mm}$ and d, depth $150 \mathrm{~mm}$ in a simply supported position. Three sample specimens were tested for each testing day after curing by ponding and the average of them all was considered as the flexural strength in $\mathrm{N} / \mathrm{mm}^{2}$. This process of a beam loaded at the third points and subjected failure load P determined the flexural strength. Equation 2 is a useful formula to determine the flexural strength of the specimen beam $550 \mathrm{~mm}$ by $150 \mathrm{~mm}$ by $150 \mathrm{~mm}$ at failure.

Flexural strength $=\frac{P L}{b d^{2}}$

Where, $\mathrm{P}$ is the failure load, $\mathrm{L}$ is the span length, $\mathrm{b}$ is specimen width and $\mathrm{d}$ is the specimen depth.

It is pertinent to note that three sample specimens were tested on each testing day and the average of them all was considered as the flexural strength in $\mathrm{N} / \mathrm{mm}^{2}$.

\section{Compression strength test:-}

The $150 \mathrm{~mm} \times 150 \mathrm{~mm} \times 150 \mathrm{~mm}$ concrete cubes were tested individually at 7 days and 28 days after being removed from the clear water curing tank on each testing day in accordance to BS EN 12390 (2009). Three cubes were tested per testing day using a calibrated compression machine inside the laboratory under the care of competent personnel. Each cube tested has the face perpendicular to the casting face and the machine exerts a constant compressive progressing force on the cube till it fails at a loading rate of $0.6 \pm 0.2 \mathrm{~N} / \mathrm{mm}^{2} / \mathrm{s}$. The maximum compressive strength of the concrete is based upon the reading of the testing machine at failure. Equation 3 is a useful formula to determine the compressive strength of the specimen beam $150 \mathrm{~mm}$ by $150 \mathrm{~mm}$ by $150 \mathrm{~mm}$ at failure.

Compressive strength $=\frac{P}{b d}$

Where, $\mathrm{P}$ is the failure load, $\mathrm{b}$ is specimen width and $\mathrm{d}$ is the specimen depth. The average compressive strength value of the three specimens tested per curing age was chosen as the compressive strength in $\mathrm{N} / \mathrm{mm}^{2}$.

\section{Tensile splitting strength test:-}

Each hardened concrete cylinder specimen of $150 \mathrm{~mm}$ diameter by $300 \mathrm{~mm}$ high was subjected to a compressive load for tensile splitting strength test at a constant rate of $400 \mathrm{~N} / \mathrm{s}$ along the length of the cylinder until failure occurred in accordance to ASTM C 496 (2011).

Tensile Splitting strength $=\frac{2 P}{\pi L d^{2}}$

Where, $\mathrm{P}$ is the failure load, $\mathrm{L}$ is the span length and $\mathrm{d}$ is the specimen diameter. On each testing day, three specimens were tested and the mean value of them is considered as the tensile strength.

\section{Results and Discussions:-}

In this study, four different types of cement which are $42.5 \mathrm{Rd}, 32.5 \mathrm{Rs}, 42.5 \mathrm{~Np}$ and $32.5 \mathrm{Rt}$ have been used to produce concrete specimens independently. In the facet, nominal maximum grading sizes $19 \mathrm{~mm}$ granite was employed along with using river sand as fine aggregate and potable water. The separate fresh and hardened concrete samples produced were tested in relationship to the standard specification requirements for highway pavement material properties for design and construction.

The cements properties and trends:-

All the four brands of cements used in this research possessed the required oxide composition but the way they complied with the standard specification requirements are not the same. The values of the oxide compositions of the individual four brands of the Portland cement employed in percent and the level at which each one complied or failed to conform with the standard specification requirements are presented in Table 6. Specifically, it could be seen 
in each of the four brands of cement, the amount of $\mathrm{CaO}$ and $\mathrm{SiO}_{2}$ are more than $80 \%$ of total oxide composition and this is in conformity with the standard specification requirements for portland cement. Also, the potential compound compositions of the Nigerian produced portland cements used in this study are compared favourably with standard specification requirements as shown in Table 7. Table 8 is showing how satisfactorily the physical and mechanical properties of the Nigerian produced Portland cements used in this study conformed to the standard specification requirements.

All the four brands of cements conformed to the standard specification while considering both the initial and final setting times as shown in Table 9. However, as seen also in Table 9, the compressive strengths of both $42.5 \mathrm{Rd}$ and 42.5 Np cement cubes are similar and are of higher values than those of same while producing with $32.5 \mathrm{Rs}$ and 32.5 Rt cements separately. It is appropriate to note that both $32.5 \mathrm{Rs}$ and $32.5 \mathrm{Rt}$ cement cubes have similar values of compressive strength also.

\section{The aggregates properties and trends:-}

Table 10 is showing the physical properties of the employed river sand as fine aggregate along with grade $19 \mathrm{~mm}$ granite as coarse aggregate. The result of the river sand shows it is a fine aggregate and coarser material. The river sand employed in this study is of well graded aggregate while the grade $19 \mathrm{~mm}$ maximum nominal size granite is of uniformly graded aggregate based upon grain size distribution curves of Figures 1 and 2.

It is pertinent to note that the values of the bulk density and specific gravity as obtained for fine and coarse aggregates used as revealed in Table 10 satisfied the standard specification requirements for concrete production. The moisture absorption values of the aggregates used in the production of laboratory specimens showed that they have been air dried before use. It must also be noted that the $19 \mathrm{~mm}$ coarse aggregate crushing, impact and Los Angeles abrasion values obtained individually are within the acceptable standard specifications.

Table 6:- Chemical composition in percent of the four cements used

\begin{tabular}{|c|c|c|c|c|c|c|}
\hline & \multicolumn{4}{|c|}{ Mineral Composition (\%) } & \multirow{2}{*}{$\begin{array}{l}\text { Specification } \\
\text { Requirements }\end{array}$} & \multirow{2}{*}{$\begin{array}{l}\text { Remarks in relationship to } \\
\text { specification requirements }\end{array}$} \\
\hline Label & $\begin{array}{l}42.5 \\
\text { Rd } \\
\text { Cement }\end{array}$ & $\begin{array}{l}32.5 \mathrm{Rs} \\
\text { Cement }\end{array}$ & $\begin{array}{l}42.5 \\
\mathrm{~Np} \\
\text { Cement }\end{array}$ & $\begin{array}{l}32.5 \mathrm{Rt} \\
\text { Cement }\end{array}$ & & \\
\hline Silicon Dioxide,$\left(\mathrm{SiO}_{2}\right)$ & 19.18 & 20.32 & 22.00 & 21.21 & $18.70-22.00$ & $\begin{array}{l}\text { All the four brands of } \\
\text { cement used complied }\end{array}$ \\
\hline Aluminium Oxide, $\left(\mathrm{Al}_{2} \mathrm{O}_{3}\right)$ & 4.89 & 4.46 & 6.12 & 4.79 & $4.70-6.30$ & $\begin{array}{l}32.5 \text { Rs cement has lower } \\
\text { value to specification but } \\
\text { other brand of cements used } \\
\text { complied. }\end{array}$ \\
\hline Iron oxide, $\left(\mathrm{Fe}_{2} \mathrm{O}_{3}\right)$ & 0.79 & 0.96 & 1.28 & 1.03 & $1.60-4.40$ & $\begin{array}{l}\text { None of the four brands of } \\
\text { cement used complied. }\end{array}$ \\
\hline Calcium Oxide, $(\mathrm{CaO})$ & 64.29 & 63.78 & 63.85 & 64.12 & $60.66-66.30$ & $\begin{array}{l}\text { All the four brands of } \\
\text { cement used complied }\end{array}$ \\
\hline Sulphur Trioxide, $\left(\mathrm{SO}_{3}\right)$ & 1.04 & 1.16 & 1.21 & 1.35 & $1.80-4.6$ & $\begin{array}{l}\text { None of the four brands of } \\
\text { cement used complied. }\end{array}$ \\
\hline Sodium Oxide, $\left(\mathrm{Na}_{2} \mathrm{O}\right)$ & 0.43 & 0.67 & 0.54 & 1.11 & $0.11-1.20$ & $\begin{array}{l}\text { All the four brands of } \\
\text { cement used complied. }\end{array}$ \\
\hline Potassium Oxide, $\left(\mathrm{K}_{2} \mathrm{O}\right)$ & 0.37 & 0.41 & 0.33 & 0.78 & $0.11-1.20$ & $\begin{array}{l}\text { All the four brands of } \\
\text { cement used complied. }\end{array}$ \\
\hline Magnesium Oxide,(MgO) & 2.22 & 2.1 & 2.82 & 3.69 & $0.70-4.20$ & $\begin{array}{l}\text { All the four brands of } \\
\text { cement used complied }\end{array}$ \\
\hline Lead oxide, $(\mathrm{PbO})$ & 0 & 0 & 0 & 0 & & $\begin{array}{l}\text { The values obtained are the } \\
\text { same. }\end{array}$ \\
\hline Calcium hydroxide & 0.39 & 0.52 & 0.31 & 0.71 & & $\begin{array}{l}\text { The values obtained are not } \\
\text { similarly. }\end{array}$ \\
\hline
\end{tabular}


Table 7:- Potential compound composition of the Nigerian produced Portland cements used in this study

\begin{tabular}{|l|c|c|c|c|c|l|}
\hline \multicolumn{1}{|c|}{$\begin{array}{c}\text { Compound } \\
\text { Composition }\end{array}$} & $\begin{array}{l}\mathbf{4 2 . 5} \mathbf{R d} \\
\text { Cement }\end{array}$ & $\begin{array}{l}\text { 32.5 Rs } \\
\text { Cement }\end{array}$ & $\begin{array}{c}\mathbf{4 2 . 5} \mathbf{~ N p} \\
\text { Cement }\end{array}$ & $\begin{array}{l}\text { 32.5 Rt } \\
\text { Cement }\end{array}$ & $\begin{array}{l}\text { Specification } \\
\text { Requirements }\end{array}$ & $\begin{array}{l}\text { Remarks } \\
\text { relationship } \\
\text { specification } \\
\text { requirements }\end{array}$ \\
\hline $\begin{array}{l}\text { Tricalcium } \\
\text { Silicate, C3S }\end{array}$ & 79 & 70 & 45 & 70 & $40-63$ & $\begin{array}{l}\text { Only cement brand } 42.5 \\
\text { Np complied of the four } \\
\text { cements }\end{array}$ \\
\hline $\begin{array}{l}\text { Dicalcium } \\
\text { Silicate, C2S }\end{array}$ & 5 & 6 & 30 & 8 & $9-31$ & $\begin{array}{l}\text { Only cement brand 42.5 } \\
\text { Np Powermax complied } \\
\text { of the four cements }\end{array}$ \\
\hline $\begin{array}{l}\text { Tricalcium } \\
\text { Aluminate, C3A }\end{array}$ & 12 & 10 & 14 & 11 & $6-14$ & $\begin{array}{l}\text { All the four brands of } \\
\text { cement complied }\end{array}$ \\
\hline $\begin{array}{l}\text { Tetracalcium } \\
\text { Aluminoferrite, } \\
\text { C4AF }\end{array}$ & 2 & 3 & 5 & 3 & $5-13$ & $\begin{array}{l}\text { Only cement brand 42.5 } \\
\text { Np complied of the four } \\
\text { cements }\end{array}$ \\
\hline
\end{tabular}

Table 8:- Physical and mechanical properties of the Nigerian produced Portland cements used in this study

\begin{tabular}{|l|c|c|c|c|c|l|}
\hline Parameters & $\begin{array}{l}42.5 \text { Rd } \\
\text { Cement }\end{array}$ & $\begin{array}{l}32.5 \mathrm{Rs} \\
\text { Cement }\end{array}$ & $\begin{array}{l}42.5 \mathrm{~Np} \\
\text { Cement }\end{array}$ & $\begin{array}{l}32.5 \mathrm{Rt} \\
\text { Cement }\end{array}$ & $\begin{array}{l}\text { Specification } \\
\text { Requirements }\end{array}$ & $\begin{array}{l}\text { Remarks in relationship to } \\
\text { specification requirements }\end{array}$ \\
\hline $\begin{array}{l}\text { Specific Gravity } \\
\mathrm{VG}\end{array}$ & 3.15 & 3.15 & 3.15 & 3.15 & $3.13-3.15$ & $\begin{array}{l}\text { All the four brands of cements } \\
\text { conformed to the standard } \\
\text { specification }\end{array}$ \\
\hline $\begin{array}{l}\text { Bulk Density, } \mathrm{Vb} \\
\mathrm{kg} / \mathrm{m}^{3}\end{array}$ & 1126 & 1100 & 1180 & 1063 & $1000-1300$ & $\begin{array}{l}\text { All the four brands of cements } \\
\text { conformed to the standard } \\
\text { specification }\end{array}$ \\
\hline $\begin{array}{l}\text { Fineness, \% } \\
\text { retained on 45 } \mu \mathrm{m}\end{array}$ & 9 & 13 & 8 & 15 & 10 maximum & $\begin{array}{l}\text { 42.5 Rd and 42.5 Np cements } \\
\text { conformed but 32.5 Rs and } \\
\text { 32.5 Rt did not conform to the } \\
\text { standard specification }\end{array}$ \\
\hline $\begin{array}{l}\text { Standard } \\
\text { consistency time }\end{array}$ & $33.1 \%$ & $33.5 \%$ & $31.5 \%$ & $32.9 \%$ & $\begin{array}{l}\text { All the four brands of cements } \\
\text { are of the same value }\end{array}$ \\
\hline $\begin{array}{l}\text { Standard } \\
\text { consistency }\end{array}$ & 0.006 & 0.008 & 0.006 & 0.002 & $0.04-0.05$ & $\begin{array}{l}\text { All the four brands of cements } \\
\text { are similarly comparable }\end{array}$ \\
\hline $\begin{array}{l}\text { Loss of Ignition, } \\
\text { LOI }\end{array}$ & 0.00 & 0.00 & 0.00 & 0.00 & $\begin{array}{l}\text { None of the four brands of } \\
\text { cements conformed to the } \\
\text { standard specification }\end{array}$ \\
\hline Fibre & 99.41 & 99.58 & 99.39 & 99.65 & $99.95-99.97$ & $\begin{array}{l}\text { All the four brands of cements } \\
\text { are of same value }\end{array}$ \\
\hline $\begin{array}{l}\text { Insoluble Residue, } \\
\text { IR }\end{array}$ & $\begin{array}{l}\text { None of the four brands of } \\
\text { cements conformed to the } \\
\text { standard specification }\end{array}$ \\
\hline
\end{tabular}

Table 9:- The cements used pastes setting times and compressive strengths properties

\begin{tabular}{|c|c|c|c|c|c|c|}
\hline \multirow{3}{*}{$\begin{array}{l}\text { Cement Used } \\
\text { Brands }\end{array}$} & \multicolumn{2}{|l|}{ Setting Time } & \multirow{2}{*}{\multicolumn{4}{|c|}{$\begin{array}{l}\text { Compressive strength } \\
\text { Curing Ages of the cement cubes }\end{array}$}} \\
\hline & \multirow{2}{*}{$\begin{array}{l}\text { Initial Setting Time in } \\
\text { minutes }\end{array}$} & \multirow{2}{*}{$\begin{array}{l}\text { Final Setting Time in } \\
\text { minutes } \\
\text { Standard Specification } \\
6.25 \mathrm{hr} .-10 \mathrm{hr} \text {. }\end{array}$} & & & & \\
\hline & & & 3days & 7days & 14days & 28days \\
\hline $42.5 \mathrm{Rd} \mathrm{OPC}$ & 2hrs. 35 mins & 4hrs. 27 mins & 11.73 & 11.96 & 12.37 & 13.00 \\
\hline 32.5 Rs OPC & 2hrs. 17 mins & 3 hrs 20 mins & 11.72 & 11.85 & 12.30 & 12.57 \\
\hline $42.5 \mathrm{Rp}$ OPC & 2hrs. 40mins & 4hrs. $59 \mathrm{mins}$ & 11.79 & 12.16 & 12.57 & 13.03 \\
\hline $32.5 \mathrm{Rt}$ OPC & 1hr. 34 mins & 3hrs. $05 \mathrm{mins}$ & 11.70 & 11.82 & 12.28 & 12.53 \\
\hline
\end{tabular}


Table 10:- Physical properties of fine and coarse aggregates used in this study

\begin{tabular}{|l|l|c|c|}
\hline S/No & Physical Properties & $\begin{array}{l}\text { Fine Aggregate } \\
\text { River Sand }\end{array}$ & $\begin{array}{l}\text { Coarse Aggregate } \\
\text { 19 mm Granite }\end{array}$ \\
\hline $\mathbf{1}$ & Percent of particles retained on the 4.75 mm sieve & 10.24 & 100 \\
\hline $\mathbf{2}$ & Percent of particles passing the 4.75 mm sieve & 96.38 & 0 \\
\hline $\mathbf{4}$ & Percent of particles passing the 0.075 mm sieve & 0.10 & 0 \\
\hline $\mathbf{5}$ & Fineness modulus & 3.000 & - \\
\hline $\mathbf{6}$ & Coefficient of uniformity (Cu) & 2.43 & 1.68 \\
\hline $\mathbf{7}$ & Coefficient of curvature (Cc) & 1.07 & 1.24 \\
\hline $\mathbf{8}$ & Bulk density & 1509 & 2.68 \\
\hline $\mathbf{9}$ & Specific gravity & 2.67 & 0.6 \\
\hline $\mathbf{1 0}$ & Moisture (water) absorption (\%) & 1.15 & 19.15 \\
\hline $\mathbf{1 1}$ & Aggregate crushing value (\%) & - & 11.95 \\
\hline $\mathbf{1 2}$ & Aggregate impact value (\%) & - & 13.95 \\
\hline
\end{tabular}

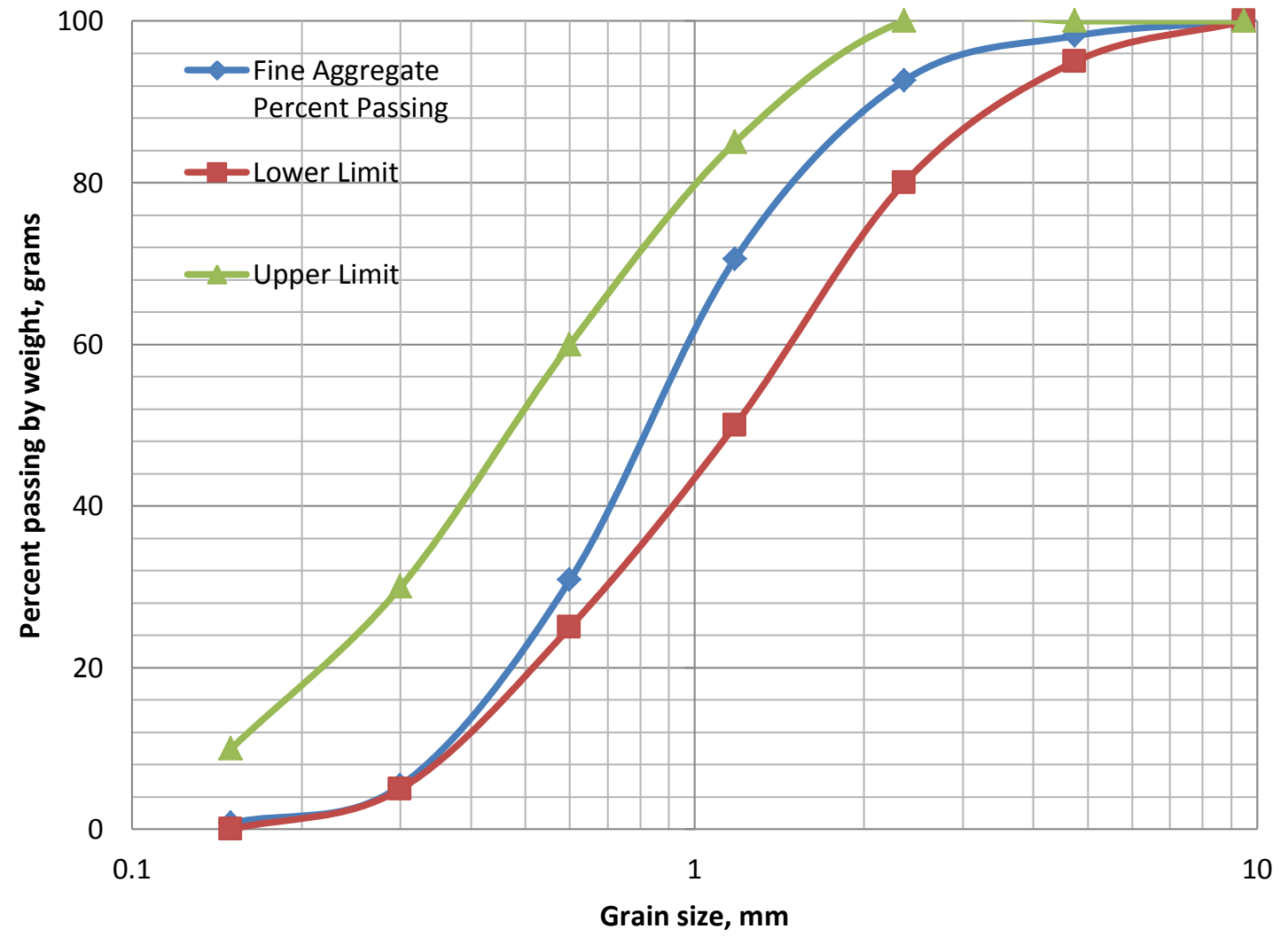

Figure 1:- The river sand fine aggregate size distribution curve 


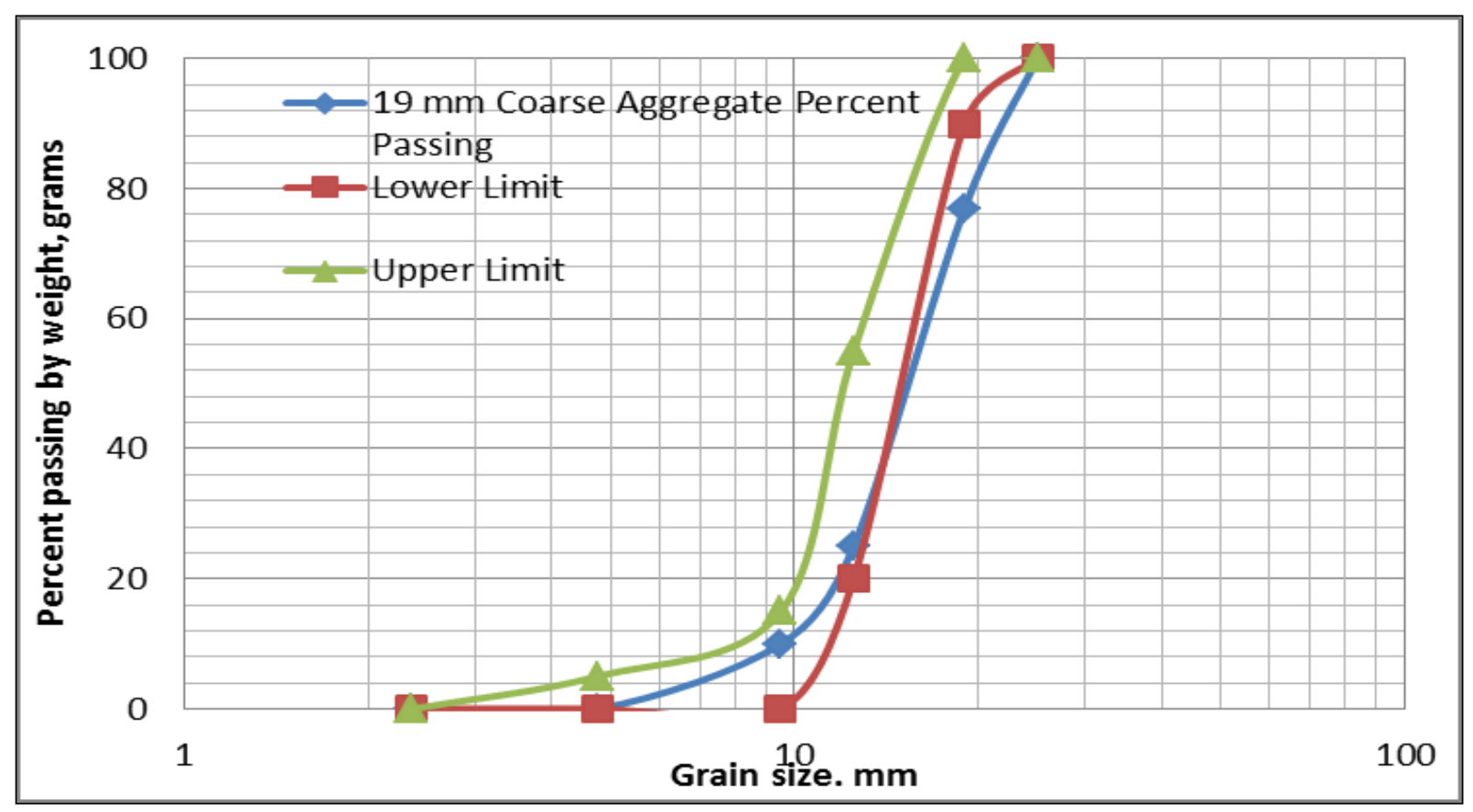

Figure 2:- $19 \mathrm{~mm}$ granite grain size distribution curve

The fresh concrete properties and trend:-

Each fresh concrete produced using individual cement brand and $19 \mathrm{~mm}$ coarse aggregate in this study was examined by slump and compacting factor tests within the first 6 minutes of production. The consistency test results as shown in Table 11 varied from height of $30 \mathrm{~mm}$ to $35 \mathrm{~mm}$ and of true slump with medium (plastic) degree of workability.

The compacting factor test results by defining the degree of workability of the fresh concrete produced while using grade $19 \mathrm{~mm}$ and grade $25 \mathrm{~mm}$ granites individually and while employing the four brands of cements separately are in Table 11. It is shown in Table 11 that the compacting factor values of the cement concrete produced varied from 0.97 of high flowing degree of workability to 0.84 of low stiff-plastic.

Table 11:- Workability properties of the fresh concretes produced using grade $19 \mathrm{~mm}$ granite by slump tests results

\begin{tabular}{|l|l|l|l|c|l|}
\hline Cement & $\begin{array}{l}\text { Height of Slump } \\
(\mathrm{mm})\end{array}$ & $\begin{array}{l}\text { Degree of } \\
\text { workability }\end{array}$ & $\begin{array}{l}\text { Slump } \\
\text { Type }\end{array}$ & $\begin{array}{l}\text { Compacting } \\
\text { Factor }\end{array}$ & $\begin{array}{l}\text { Degree } \\
\text { Workability }\end{array}$ \\
\hline 42.5 Rd OPC & 32 & Medium (Plastic) & True slump & 0.9 & Medium (Plastic) \\
\hline 32.5 Rs OPC & 33 & Medium (Plastic) & True slump & 0.94 & Medium (Plastic) \\
\hline 42.5 Rp OPC & 30 & Medium (Plastic) & True slump & 0.84 & Low (Stiff-Plastic) \\
\hline 32.5 Rt OPC & 35 & Medium (Plastic) & True slump & 0.97 & Medium (Plastic) \\
\hline
\end{tabular}

\section{The hardened concrete specimens properties and trends:-}

Flexural strength values obtained upon testing hardened beam concrete specimens cured with water by ponding in the course of this study are shown in Table 12. It could be seen in Table 12 that the flexural strength values of the specimens obtained as at each testing day is higher as the number of water curing days are increasing comparable for each of the cement brand used. At 28 day water curing strength tests results, concrete specimen using ordinary portland (OPC) cement tagged $42.5 \mathrm{~Np}$ has the highest value while that of $32.5 \mathrm{Rt}$ has the lowest value. Also, in Table 12 it could be seen vividly that as the curing age increases the flexural strength concrete specimens are increasing. In the facet, the value in percent of flexural strength of 7 days water curing is lower to that of 28 days. It is pertinent to note that cements tagged with $\mathrm{R}$ have higher percentages than that of $\mathrm{N}$ while considering 7 days curing flexural strength which distinguished the three brands of cement as rapid while the remaining one is nominal cement. On the other side the values in percent of flexural strength of 56 days, 91 days and 120 days water curing are respectively higher than those of respective 28 days curing. 
The compressive strength and tensile strength tests comparative results of the concrete cube specimens using individually the four different types of cements for the production of concrete specimens separately are in Table 13. Also, as seen in Table 13, the values of the compressive strength and tensile strength of cement tagged $42.5 \mathrm{~Np}$ is the highest while that of $32.5 \mathrm{Rt}$ is the lowest.

Table 12:- Relative flexural strength of hardened concrete per curing ages

\begin{tabular}{|c|c|c|c|c|c|c|c|c|c|c|}
\hline \multirow{2}{*}{$\begin{array}{l}\text { Mix } \\
\left(1: 1 \frac{1 / 2: 3) ;}{} \text { w/r }(0.4)\right. \\
\\
\text { Curing ages }\end{array}$} & \multicolumn{5}{|c|}{ 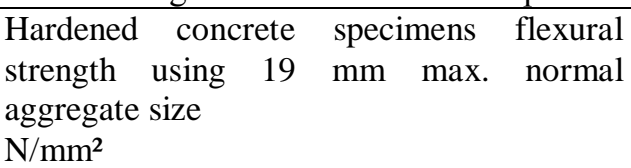 } & \multicolumn{5}{|c|}{$\begin{array}{l}\text { Hardened concrete specimens flexural strength } \\
\text { using } 19 \mathrm{~mm} \text { max. normal aggregate size in } \\
\text { percent relationship to } 28 \text { days water curing } \\
(\%)\end{array}$} \\
\hline & 7 days & $\begin{array}{c}28 \\
\text { days }\end{array}$ & $\begin{array}{c}56 \\
\text { days }\end{array}$ & $\begin{array}{c}91 \\
\text { days }\end{array}$ & $\begin{array}{l}120 \\
\text { days }\end{array}$ & $\begin{array}{c}7 \\
\text { days }\end{array}$ & $\begin{array}{c}28 \\
\text { days }\end{array}$ & $\begin{array}{c}56 \\
\text { days }\end{array}$ & $\begin{array}{c}91 \\
\text { days }\end{array}$ & 120 days \\
\hline OPC $42.5 \mathrm{Rd}$ & 3.4 & 4.1 & 5.2 & 5.4 & 5.6 & 83 & 100 & 127 & 132 & 137 \\
\hline OPC 32.5 Rs & 3.4 & 3.8 & 4.4 & 4.8 & 4.8 & 89 & 100 & 116 & 126 & 12 \\
\hline OPC $42.5 \mathrm{~Np}$ & 3.6 & 4.8 & 5.3 & 5.5 & 6 & 75 & 10 & 110 & 115 & 125 \\
\hline OPC $32.5 \mathrm{Rt}$ & 3.2 & 3.6 & 4.1 & 4.2 & 4.6 & 89 & 100 & 114 & 117 & 128 \\
\hline
\end{tabular}

Table 13: Compressive and tensile strengths of hardened concrete per curing ages, using $19 \mathrm{~mm}$ maximum normal aggregate size

\begin{tabular}{|l|c|c|c|c|c|c|c|c|}
\hline $\begin{array}{c}\text { Mix Ratio } \\
(1: 1 / 2: 3) \\
\text { w/r (0.4) }\end{array}$ & $\begin{array}{c}\text { Hardened } \\
\text { Concrete } \\
\text { Specimens } \\
\text { Compressive } \\
\text { Strength } \\
\left(\mathrm{N} / \mathrm{mm}^{2}\right)\end{array}$ & $\begin{array}{c}\text { Hardened Concrete } \\
\text { Specimens } \\
\text { Compressive Strength } \\
\text { Percent Increase In } \\
\text { Relationship To 28 } \\
\text { Days Water Curing } \\
(\%)\end{array}$ & $\begin{array}{c}\text { Hardened Concrete } \\
\text { Specimens Tensile } \\
\text { Strength }\end{array}$ & \multicolumn{2}{c|}{$\begin{array}{c}\text { Hardened Concrete } \\
\text { Specimens Tensile } \\
\text { Strength } \\
\text { Percent Increase In } \\
\text { Relationship To 28 } \\
\text { Days Water Curing } \\
(\%)\end{array}$} \\
\hline Curing ages & 7 days & 28 & 7 days & 28 days & 7 days & 28 days & 7 days & 28 days \\
\hline OPC 42.5 Rd & 27.7 & 32.5 & 85 & 100 & 2.0 & 2.4 & 83 & 100 \\
\hline OPC 32.5 Rs & 26.5 & 31.5 & 84 & 100 & 1.9 & 2.3 & 83 & 100 \\
\hline OPC 42.5 Np & 29.3 & 34.6 & 85 & 100 & 2.3 & 2.9 & 79 & 100 \\
\hline OPC 32.5 Rt & 25.7 & 30.5 & 84 & 100 & 1.9 & 2.2 & 86 & 100 \\
\hline
\end{tabular}

\section{Conclusions and Recommendations:-}

The conclusions and recommendations proffered are upon concretes specimens produced by the four different types of newly improved portland cement that are made in Nigeria. The brands of cements are respectively tagged 42.5 $\mathrm{Nd}, 32.5 \mathrm{Rs}, 42.5 \mathrm{~Np}$ and $32.5 \mathrm{Rt}$ for the purposes of laboratory investigations that are described next.

\section{Conclusions:-}

Based upon the laboratory experiments that have been carried out in this research work, the following are the proffered conclusions.

1. The four newly improved brands of portland cements tagged $42.5 \mathrm{Nd}, 32.5 \mathrm{Rs}, 42.5 \mathrm{~Np}$ and $32.5 \mathrm{Rt}$ brands used individually in this research conformed satisfactorily at very good level to ASTM, AASHTO, British and Nigerian relevant standard specification requirements.

2. Table 3 is a useful paradigm of using expressions for the computations of the absolute volume and weight of a batch for concrete production involving the use of admixture.

3. Table 4 is a useful modelling module that forms a template through the use of Microsoft Excel spreadsheet for actualization of the volume and weight values of a batch for concrete production.

4. Table 5 simulated accurately the results proffered by the modelling work of Table 4 and identified vividly the difference between the applied ratios by weight. The methodology is useful in the laboratory for concrete research work or at the manufacturing yards for the material to be transported to the construction sites. Whilst by volume is beneficial at the construction site by labour work and the use of concrete mixer.

5. Each cement brand physical, chemical, potential compound compositions, fineness, specific gravity, bulk density, insoluble residue and loss of ignition properties conformed to the standards requirements satisfactorily 
as shown in Tables 6,7 and 8. Also, each cement setting times and compressive strength also conformed favourably well with the specification standards as in Table 8.

6. As shown in Table 9 and Figure 1 the river sand used is a coarse uniformly graded fine aggregate. Also, considering Table 9 and Figure 2 the granite used is of grade $19 \mathrm{~mm}$ and was found to be uniformly graded dense coarse aggregate.

7. Of the four different types of cement used in this research, only concrete produced using $42.5 \mathrm{~Np}$ cement with the use of $19 \mathrm{~mm}$ granite attained the flexural strength value of $4.8 \mathrm{~N} / \mathrm{mm}^{2}$ that satisfied the $4.5 \mathrm{~N} / \mathrm{mm}^{2}$ requirements for highway pavement design and construction at 28 days curing in water by ponding.

\section{Recommendations:-}

The laboratory experiments carried out in this research have allowed for the following recommendations.

1. The result of workability by compacting factor test is endorsed as a measure of concrete consistency at a higher degree than that of slump test as shown in this research work for being related well to the results of hardened concrete strength tests.

2. The use of 1:1.5:3 concrete mixture of only cement tagged $42.5 \mathrm{~Np}$, river sand, $19 \mathrm{~mm}$ granite and water-cement ratio 0.4 as used in this research that attained the flexural strength of $4.8 \mathrm{~N} / \mathrm{mm}^{2}$ at 28 days water curing by submersion is recommended satisfactorily for highway rigid pavement construction.

3. Further work is necessary to define the possibility of making use of $25 \mathrm{~mm}$ granite whenever it is the only available aggregate to attain minimum flexural strength of $4.5 \mathrm{~N} / \mathrm{mm}^{2}$ at 28 days water curing by ponding along with the use of 1:1.5:3 concrete mixture of cement tagged $42.5 \mathrm{~Np}$ and river sand.

4. Further work is also necessary to define the possibility of making use of other cement brands employed in this research to produce concrete to satisfy minimum flexural strength of $4.5 \mathrm{~N} / \mathrm{mm}^{2}$ at 28 days water curing by submersion along upon using granite $19 \mathrm{~mm}$.

\section{References:-}

1. Mamlouk, M. M and Zaniewski, J. P. (2006): "Materials for Civil and Construction Engineers", Pearson Education, Inc., Upper Saddle River, New Jersey

2. ASTM C33 / C33M (2016): "Standard Specification for Concrete Aggregates", American Society for Testing and Materials, 100 Barr Harbor Drive, West Conshohocken, PA 19428-2959

3. AASHTO M 6 (2013): "Standard Specification for Fine Aggregate for Portland Cement Concrete Standard", American Association of State and Highway Transportation Officials, Washington, D.C

4. Ikponmwosa, E. E., Salau, M. A. and Olonade, K. A. (2014): "Suitability of crushed palm kernel shell as coarse aggregate in structural concrete", Current Advances in Civil Engineering, CACE Volume 2, Issue 2 PP.59-67

5. Wright, P. H and Dixon, K. H. (2004) "Highway Engineering", John Wiley and Son, New York, NY, USA, 7th edition

6. O'Flaherty, C. A. (2002): "Concrete pavement construction", in Highways, the Location, Design, Construction \& Maintenance of Pavement, edited by O'Flaherty, C. A.

7. AASHTO T 85 (2009): "Standard Specification for Portland cement (Chemical and Physical)", American Association of State Highway and Transportation Officials, Washington, D.C.

8. ASTM C 188 (2015): "Standard Test Method for Density of Hydraulic Cement, density, hydraulic cement, specific gravity", American Society for Testing and Materials, 100 Barr Harbor Drive, West Conshohocken, PA 19428-2959

9. ASTM C 430 (2008): "Standard Test Method for Fineness of Hydraulic Cement by the 45- $\mu$ m (No. 325) Sieve", American Society for Testing and Materials, 100 Barr Harbor Drive, West Conshohocken, PA 194282959

10. ASTM C 191 (2013): "Standard Test Methods for Time of Setting of Hydraulic Cement by Vicat Needle", American Society for Testing and Materials, 100 Barr Harbor Drive, West Conshohocken, PA 19428-2959

11. AASHTO T 27 (2014): "Standard Method of Test for Sieve Analysis of Fine and Coarse Aggregates", American Association of State Highway and Transportation Officials, Washington, D.C

12. AASHTO T 84 (2013): "Standard Method of Test for Specific Gravity and Absorption of Fine Aggregate", American Association of State Highway and Transportation Officials, Washington, D.C

13. AASHTO T 19 (2014): "Standard Method of Test for Bulk Density ('Unit Weight') and Voids in Aggregate", American Association of State Highway and Transportation Officials, Washington, D.C

14. Gambhir, M. L.(2004): "Concrete Technology" Tata McGraw-Hill publishing Company Limited, 7 West Patel Nagar, New Delhi 110008 
15. AASHTO T 119 (2013): "Standard Method of Test for Slump of Hydraulic Cement Concrete", American Society for Testing and Materials, 100 Barr Harbor Drive, West Conshohocken, PA 19428-2959

16. Akiije, I. (2017): "Effects of CONPLAST SP 430 Superplasticizer Using Four Nigerian Produced Cements Individually In Concrete Production for Highway Pavement," Journal of Multidisciplinary Engineering Science and Technology (JMEST) Vol. 4 Issue 6 PP 7480-7491

17. BS 1881 (2011): "Testing concrete", British Standards Institution, London

18. ASTM C 78 (2016): "Standard Test Method for Flexural Strength of Concrete (Using Simple Beam with ThirdPoint Loading)", American Society for Testing and Materials, 100 Barr Harbor Drive, West Conshohocken, PA 19428-2959

19. BS EN 12390 (2009): “Testing Hardened Concrete - Making \& Curing Specimens for Strength Tests”, British Standards Institution, London

20. ASTM C 496 (2011): "Standard Test Method for Splitting Tensile Strength of Cylindrical Concrete Specimens, cylindrical concrete specimens, splitting tension, tensile strength", American Society for Testing and Materials, 100 Barr Harbor Drive, West Conshohocken, PA 19428-2959 